\title{
Diaspora ortodoxă: analiză, nuanțare și redefinire
}

\author{
Răzvan BRUDIU * \\ Alexandru CIUCURESCU **
}

Abstract: The Orthodox Diaspora: Analysis, Nuance and Definition $^{* * *}$. The reasons why a diaspora appears are similar throughout human history. People are ontologically the same, and the social, cultural, and religious context in which these great migrations take place is often similar. We can identify distinct elements and mutual lessons that help us to understand these events much better, to prevent them by noticing the causes in time, and to learn from these lessons of past and present history. The present study focuses, on the one hand, on the effects that the phenomenon of migration has had on the Orthodox diaspora, especially given the religious and social impact of life that today's Orthodox have among foreigners, being far from their national, religious and cultural center. The diaspora is essentially experiencing a revitalization of the faith in a foreign country and among people professing foreign beliefs. Thus, in the Church, all nationalist nostalgia should be overcome, because the Church is a foreshadowing of the Kingdom, where there is neither Greek nor Jew [...] because we are all one in Christ Jesus (Gal 3:28). Thus, wherever we live, we are always in the "diaspora", even within the boundaries drawn by our forerunners, in the land they inhabited. On the other hand, the present research also deals

* Diacon, Lector universitar la Facultatea de Teologie Ortodoxă, Universitatea „1 Decembrie 1918" din Alba Iulia, România.

** Doctorand în Teologie al Facultății de Teologie Ortodoxă, Universitatea BabeșBolyai din Cluj-Napoca, România.

*** Studiul de față este publicat și în limba engleză în International Journal of Orthodox Theology 12:1 (2021). 
with the issue of mixed marriages. The issue urged the Orthodox to look beyond the canonical perspective of impediments to marriage and to focus on more urgent issues that require attention, namely the liturgical, pastoral and ecumenical aspects of mixed marriages. However, given the ethnic and cultural diversity in which the Orthodox Church carries out its mission in the world today, we should not be surprised that each Orthodox Church has applied and continues to apply the principles of canonical eikonomia and akribeia to mixed marriages in a non-unitary manner.

Keywords: Orthodox diaspora, mixed marriages, jurisdiction-territory, ethnophyletism, eikonomia, akribeia.

\section{1. „Exilul” românesc - context istoric și repercusiuni sociale și religioase}

Secolele XX și XXI au avut de-a face cu valuri mari de migrație din motive economice care au oferit baza creării diasporelor moderne sau au adăugat membri comunităților din jurul lumii, din diaspore pre-existente. Mai mult, conceptele „,permanent” și „temporar” tind să se amestece sau, cel puțin, să devină imprecise în lumea globalizată unde oamenii pot schimba țările de rezidență mereu și pot ocupa noi poziţii profesionale. Majoritatea vechilor diaspore au fost și ele la început alcătuite din comunități care au migrat din motive economice ${ }^{1}$.

Diaspora Ortodoxă în general și cea românească, în mod special, nu s-a născut dintr-o chemare explicită a lui Dumnezeu. În ceea ce privește cronologia „exilului” românesc, acesta se manifestă ca fenomen relativ târziu și s-a născut din rațiuni economice (la începutul secolului XX, Goana după aur sau febra aurului în Statele Unite ale Americii), politice (la jumătatea secolului XX prin instalarea sistemului concentraționar comunist est-european), iar în contemporaneitate diaspora este un trend (a se vedea recentul exod sirian). De asemenea, amintim faptul că atât după Revoluția din decembrie 1989, cât și după aderarea României la Uniunea

1 Panagoula Diamanti-Karanou, The Relationship between Homeland and Diaspora: the Case of Greece and the Greek-American community, Northeastern University Boston, Massachusetts April, 2015, p. 26. 
Europeană (2007), numărul românilor plecaţi peste hotare a crescut considerabil, estimările neoficiale vorbesc de aproximativ cinci milioane de români aflați în diasporă. După evenimentele de la sfârşitul secolului XX, Europa și-a volatilizat granițele, și-a fluidizat populațiile, pariind pe modelul maxim versatil în toate aspectele, numindu-l emfatic politică incluzivă.

Diaspora românească s-a dezvoltat exponenţial, având ca perspectivă crearea unei vieți într-o ,țară în care curge lapte și miere”. Comunitățile nou formate au temeluit și comunități parohiale noi, cu acomodări și răspunsuri noi. Fondul psihologic al memoriei afective (dorul de acasă și de cei de acasă) a constituit contextul cel mai frecvent întâlnit în Diaspora Ortodoxă românească. Nașterea de parohii noi, de eparhii noi a fost doar consecința firească. Bunăstarea nu a rezolvat problemele profunde ale înstrăinatului, iar sufletul nematerial nu poate dobândi împlinire prin bunuri materiale.

În diaspora, modul de a face vizibilă identitatea religioasă ține de un mod de supraviețuire. Majoritatea comunităților ortodoxe românești celebrează slujbele în biserici catolice sau protestante. Astfel, pentru dezvoltarea unui ambient specific ortodox, respectivele comunități recurg la diverse forme de amenajare a spațiului liturgic. În timp, unele comunități gazdă (neortodoxe) au început să accepte chipuri de sfinți sau catapetesme mobile. Prezența acestor noi elemente cultice au condus la o anumită hibridizare a spațiului bisericii gazdă. Acest mod de hibridizare se vede și în faptul că clericii ortodocși pomenesc la finalul Sfintei Liturghii nu numai sfinţii ocrotitori ai comunităţii respective, ci și sfinţii patroni ai bisericii gazdă, cel puţin aceia proveniţi din perioada primului mileniu creștin ${ }^{2}$. În viziunea profesorului $\mathrm{O}$. Mihoc, respectiva formă de hibridizare liturgică nu trebuie privită în mod obligatoriu ca fiind un fenomen sincretist, ci mai mult ca o reflecție profundă asupra modului de interacțiune între actele liturgice și spațiul liturgic.

2 Octavian Miнoc, „Identitatea religioasă ca narațiune în spaţii în constantă reconfigurare", în Biserica Ortodoxă și provocările viitorului, ed. Mihai Himcinschi/Răzvan Brudiu, Cluj-Napoca/Alba Iulia, Editura Presa Universitară Clujeană/Reîntregirea, 2020, p. 175-176. 
Episcopul Ignatie al Hușilor, care a trăit o vreme în diaspora și cunoaște pulsul acesteia, amintește că Biserica este prima și, probabil, unica instituție care ține, în mod consecvent și rectiliniu, la tot ceea ce reprezintă conceptul de identitate românească pentru cei plecaţi în diaspora. Ierarhul afirmă că Biserica este preocupată de viața duhovnicească a tuturor românilor înstrăinați și care sunt departe de cei dragi ai lor. Așadar, Biserica are grijă de credința lor, de identitatea lor și de speranța $\operatorname{lor}^{3}$. Astfel, omul din diaspora care a dobândit lucrul dorit s-a împlinit doar după aflarea Acelui Cineva Care i-a împlinit sau nu dorința. Biserica a oferit susținerea în aflarea Acelui Cineva. $\mathrm{Cu}$ toate acestea, nu întotdeauna lucrurile au funcționat optim. Adesea, misiunea Bisericii este provocată în aspecte colaterale. Adică, credincioșii săi rezonează mai intens la activități comemorative sau, altfel spus, activități care îi leagă de casă, de cei de departe. Aceste plasticizări ale memoriei afective nu reușesc, de regulă, să conecteze impecabil omul cu Dumnezeu, ci doar să definească diaspora mai ales pe considerente etnice. Paradigma modernă a diasporei nu are la bază chemarea de către Cineva, ci mirajul către un ceva. $\mathrm{Cu}$ toate acestea Biserica este cadrul cel mai adecvat de definire ontologică a omului din diaspora.

\section{Căsătoriile mixte în comunitățile ortodoxe din diaspora}

În ultimii treizeci de ani, aproximativ cinci milioane de români ortodocși au emigrat în țări din Europa de Vest. Biserica Ortodoxă Română a reuşit să îşi adapteze misiunea și pastoraţia la noua realitate, și pornind de la cele două episcopii existente, în America și în Europa Occidentală, a organizat alte cinci eparhii. Toți acești credincioși ortodocşi români trăiesc într-un context religios majoritar catolic sau protestant, ajungându-se, de multe ori, la întemeierea unor familii mixte ${ }^{4}$. In anii '60, creştinii ortodocşi din Statele Unite ale

3 †EPiscopul Ignatie, Maladia ideologiei şi terapia Adevărului, Huşi, Editura Horeb, 2020, p. 36.

4 Patriciu VlaicU, „Biserica Ortodoxă în fața problematicii căsătoriilor mixte”, în Studii Teologice, 1/2012, p. 167. 
Americii credeau că o căsătorie mixtă nu este o problemă atât de importantă. Când mitropolitul ortodox antiohian, Anthony Bashir al Americii de Nord i-a scris conaționalului său, diplomatul Charles Malik, despre starea ortodoxiei antiohiene în America de Nord, ierarhul a recunoscut că respectivele căsătorii mixte sunt o realitate, dar una uşor de controlat. Bashir estima că în anul 1965 ar fi oficiat căsătorii la aproximativ 80 de biserici care aveau aproximativ 32.000 de credincioși şi foarte rar aveau loc căsătorii mixte. Căsătoriile ce aveau loc între ortodocşi şi eterodocşi reprezentau cel mult $15 \%$ din totalul căsătoriilor care se încheiau, dar, în final, mitropolitul amintea că majoritatea, dacă nu chiar toți, erau convertiți la ortodoxie ${ }^{5}$.

Astăzi, însă, niciun reprezentant oficial al Bisericii Ortodoxe nu mai poate scrie sau vorbi cu certitudine maximă despre acest subiect. Lumea în care se găsesc creştinii ortodocşi în general şi ortodocșii români în special, îi poziționează pe aceștia în fața unor dileme provocatoare. O serie de studii și analize arată faptul că, în primul deceniu al secolului XXI, aproape jumătate dintre căsătoriile încheiate în Statele Unite sunt între persoane de credințe diferite (adică creştinii se căsătoresc cu persoane care nu sunt creştine). Mai mult, tendința este în creștere şi, de la aproximativ 19\% din totalul căsătoriilor între persoane de credințe diferite în anii ' 60 , se ajunge la 39\% din totalul căsătoriilor până în anul 2010. Una din cinci căsătorii încheiate între persoane de credinţe diferite, în zilele noastre, este făcută de creştini care se căsătoresc cu creştini neafiliați ${ }^{6}$. În anul 2007, părintele George Tsetsis a observat numărul tot mai crescut al căsătoriilor mixte şi i-a îndemnat pe ortodocşi să privească problema dincolo de perspectiva canonică a impedimentelor la căsătorie și să se aplece mai degrabă asupra unor aspecte mult mai urgente care necesită atenție, și anume, aspectele liturgice, pastorale şi ecumenice ale căsătoriilor mixte ${ }^{7}$.

5 Anthony RoEber, Mixed Marriages. An Orthodox Hystory, New York, St. Vladimir's Seminary Press, 2018, p. 11.

${ }^{6}$ Se referă la persoane care cred în Hristos, fără să se declare parte a unei Biserici sau confesiuni. A se vedea Anthony Roeber, Mixed Marriages..., p. 11-12.

${ }^{7}$ George Tsetsis, The Pastoral Dimension of Mixed Marriages, Athens, 2007, p. 599-611. Menționăm faptul că versiunea în limba engleză a acestui studiu este 
Viața creştinilor căsătoriţi este legată de credința împărtăşită în Iisus Hristos. Fără această credință comună, scopul căsătoriei este nedesăvârșit. Lipsa unei credințe creștine comune ridică problema dacă astfel de căsătorii reflectă în mod deplin relația dintre Hristos și Biserică ( $c f$. Ef 5, 21-32). Realizarea acestei imagini în viaţa conjugală presupune ca soții să experimenteze și să împărtășească dragostea lui Hristos față de Biserică, precum și supunerea Bisericii față de Hristos. $\mathrm{Cu}$ toate acestea, continuarea căsătoriilor între ortodocși și necredincioși, înainte de convertirea la credință de către unul dintre soţi, este permisă în cazuri excepționale, pe baza textului din 1 Corinteni 7, 12-14. În aceste condiții, soțului ortodox i se permite să primească respectiva comuniune matrimonială, ceea ce reprezintă aici un semn al acceptării Bisericii. Conform tradiţiei canonice ortodoxe, permisiunea pentru continuarea unor astfel de căsătorii este considerată un exerciţiu de iconomie bazat pe textul scripturistic amintit anterior. Aceeași sursă nu consideră această excepție ca un principiu general pentru membrii ortodocși în privința căsătoriei cu soți nebotezați ${ }^{8}$. Pasajul paulin (1 Co 7, 12-14) amintește de contextul în care căsătoria era tributară societăţii iudaice și păgâne, însă, cu toate acestea, același text nu ne asigură deplin că apostolii ar fi încurajat căsătoriile mixte ca mijloc misionar. Astfel, Sfântul Pavel a înțeles raportul dintre viața în Hristos și libertatea față de constrângerile legii, demonstrând, pe de-o parte, faptul că misiunea Bisericii are în vedere lucrarea credinței prin iubire și înțelegere, însă, pe de altă parte, îi îndeamnă pe creștini să se ferească de căsătoriile cu păgâni $(c f .2 \text { Co } 6,14)^{9}$. Textul paulin este formulat sub forma unui îndemn, afirmând căsătoria ca o încununare spre mântuire, iar căsătoria cu un necreștin poate fi un obstacol în această lucrare a credinței.

disponibilă la http://www.apostoliki-diakonia.gr/en_main/catehism/theologia _zoi/themata.asp?cat=poim\&contents $=$ contents.asp\&main $=$ SK_texts\&file $=4$. ht $\mathrm{m}$ (accesat la data de 16.03.2021).

${ }^{8}$ Patrick Viscuso / Kristopher L. WiLlumsen, ,Marriage between Christians and Non-Christians: Orthodox and Roman Catholic Perspectives", în Journal of Ecumenical Studies, 31:3-4, Summer-Fall 1994, p. 272.

${ }^{9}$ Patriciu Vlaicu, „Biserica Ortodoxă în fața problematicii...”, p. 169. 
Biserica Ortodoxă Română, ținând cont de realitățile pastoral-misionare prezente în societate, a reglementat acest tip de căsătorie printr-un act normativ din cadrul Regulamentului pentru relațiile bisericești ale clerului ortodox român cu creștinii eterodocși (articolul 4/1881) care oferea posibilitatea binecuvântării unei astfel de căsătorii1 ${ }^{10}$. Chiar dacă nu există un document oficial pentru încadrarea canonică și procedurală a căsătoriilor mixte, odată cu apariția Regulamentului de procedură al instanțelor disciplinare și de judecată, a fost stipulată printr-un act normativ (articolul 47/1950) posibilitatea acordării dispensei ${ }^{11}$. De asemenea, în anul 2015, Patriarhia Română a elaborat un nou document intitulat Regulamentul autorităților canonice disciplinare și al instanțelor de judecată ale Bisericii Ortodoxe Române (art. 29, paragraful 8), în care nu se amintește în mod explicit despre problema căsătoriilor mixte, menționându-se doar faptul că înaintea săvârșirii Tainei Cununiei, clericul trebuie să se încredințeze dacă mirii și nașii îndeplinesc prevederile canonice și legale. În nota de subsol a acestui paragraf sunt amintite canoanele conform cărora se poate sau nu săvârși Taina Cununiei (Canonul 72 Trullan, 14 IV Ecumenic, 10 Laodiceea, 23 Ioan Ajunătorul). În același paragraf, apare un canon în plus, celelalte fiind aceleași de la nota din paragraful 8, și anume Canonul 31 Laodiceea $^{12}$. Atât în Statutul pentru organizarea și funcționarea Bisericii Ortodoxe Române (2008), articolul 88, litera (r), cât și în Statutul pentru organizarea şi funcționarea Bisericii Ortodoxe Române (republicat în 2020), articolul 88, paragraful 23, se menționează că episcopul locului acordă dispense bisericești de căsătorie şi recăsătorire pentru credincioșii mireni, în limita prevederilor canonice.

În privința dispensei, ierarhul poate refuza acordarea acesteia dacă observă că există pericolul ca soțul ortodox sau copiii să fie

10 Ioan CozMA, „Căsătoriile mixte în teoria și practica Bisericii Ortodoxe”, în Altarul Reîntregirii, 2/2010, p. 163-164.

11 În acest sens, a se vedea Legiuirile Bisericii Ortodoxe Române, București, 1953.

${ }^{12}$ Regulamentul autorităților canonice disciplinare și al instanțelor de judecată ale Bisericii Ortodoxe Române, București, Editura Institutului Biblic şi de Misiune Ortodoxă, 2015, p. 41. 
determinaţi să se îndrepte către credința eterodoxă a celuilalt soț. De asemenea, episcopul trebuie să țină cont în acordarea dispensei și de statutul soțului eterodox, și anume dacă a mai fost sau nu căsătorit. Dacă, de exemplu, soțul ortodox se află la prima căsătorie și cel eterodox la a doua căsătorie, se va dispune săvârșirea Tainei Cununiei pentru cei care se căsătoresc prima dată; dacă soțul eterodox este la prima căsătorie, iar cel ortodox la a doua sau a treia căsătorie, se va săvârşi rânduiala specifică menționată în Molitfelnic pentru cei care se căsătoresc a doua sau a treia oară. Amintim faptul că în acest ultim caz, pentru validitatea Cununiei, soțul ortodox, pe lângă divorțul civil, trebuie să obțină din partea episcopului și divorțul religios ${ }^{13}$.

\section{Provocări pastoral-misionare ale comunităților ortodoxe din diaspora}

Diferitele tipuri de migrație și creșterea comunităților diasporale conduc inevitabil la o nouă percepție a realității și a spațiului. Multiple identităţi lingvistice, culturale, religioase și etnice sunt condensate și reprezentate în spațiul local. Toate acestea creează o nouă paradigmă de relaționare, inter-dependență, co-asumare și coresponsabilizare a diferiților factori sociali și religioși. O. Mihoc atenționează despre creșterea numărului de membri în comunitățile diasporale, care nu vin direct din țara de origine, ci din alte țări europene, cum e cazul multor comunități ortodoxe române din țările Europei de Vest, care dă naștere unui profil aparte al comunității, ai căror membri nu numai că provin din spații culturale românești diferite, ci aduc cu ei și o acumulare culturală europeană și o cetățenie multiplă. Respectivele dinamici transnaționale și transculturale recentrează problema spațiului și a capacității sale de a crea noi cadre în care aceste dinamici să se poată desfășura ${ }^{14}$.

În primul rând, sintagma Diaspora Ortodoxă acoperă o realitate sociologică și istorică: migrarea populațiilor ortodoxe către

13 Ioan COZMA, „Căsătoriile mixte în teoria...”, p. 164-165.

${ }^{14}$ Octavian MıнOC, „Identitatea religioasă ca narațiune în spații...”, p. 166-167. 
țări care nu sunt în mod tradiţional ortodoxe, formarea diasporelor naționale în țările gazdă, apariția potențială a unei diaspore religioase mai mari, adunată în jurul credinței ortodoxe ca trăsătură comună a acestor migranți etnici. În al doilea rând, Diaspora Ortodoxă conține substanță teologică: diaspora, inițial un concept religios marcat de iudaism, este folosit pentru a descrie structura şi viața sacramentală a instituțiilor religioase ortodoxe din afara teritoriilor lor tradiţionale, atingând, prin urmare, ecleziologia ortodoxă și organizarea canonică ${ }^{15}$.

Din punct de vedere misionar, configurația tradițională a Ortodoxiei s-a modificat în mod considerabil. Ortodoxia a devenit o comunitate polifonică, iar zona misionară a Ortodoxiei exprimă astăzi o mare diversitate geografică, culturală și cultică. O problemă serioasă legată de Diaspora Ortodoxă o reprezintă jurisdicția, adică aspectul dependenței canonice a comunităților din afara granițelor ${ }^{16}$. Diaspora Ortodoxă astăzi se caracterizează prin două tendințe: una care afirmă o ortodoxie autohtonă/locală și alta care conservă o ortodoxie etnică. $\mathrm{Cu}$ excepția câtorva eparhii din Biserica Ortodoxă din America, diocezele ortodoxe din Occident au un caracter etnic, element ce face destul de dificilă adaptarea teritorială a acestora și limitarea jurisdicțională a ierarhilor. Principiul organizării administrative a respectivelor comunități ortodoxe în eparhii este cel jurisdicțional, iar nu cel teritorial. Ambele principii sunt la fel de importante, însă principiul teritorialităţii este acela de a crea unitate şi nu fragmentare în interiorul Bisericii. Teritoriul canonic al unei biserici locale este un teritoriu geografic determinat în care un episcop își exercită jurisdicția ecleziastică. Un ierarh nu își poate extinde jurisdicția în afara propriului teritoriu și nici nu poate interveni în teritoriul canonic al unei alte eparhiii ${ }^{17}$.

15 Maria HÄMmERLI, „Orthodox diaspora? A sociological and theological problematisation of a stock phrase", în International Journal for the Study of the Christian Church, 10, 2-3/2010, p. 98.

16 †NIFON MIHĂIȚĂ, „Diaspora-o nouă tipologie misionară”, în Misiologie Ortodoxă, vol. I, coord. Valer Bel, București, Editura Basilica, 2021, p. 221.

17 Maria HÄMmERLI, „Orthodox diaspora? A sociological and theological problematisation...”, p. 109; Ioan COZMA, „Diaspora Ortodoxă: canonicitate și 
Diaspora face exact opusul: dacă o biserică își poate genera sau crea propria diasporă din pricina faptului că o parte a turmei sale a emigrat, atunci episcopul își poate extinde dreptul de jurisdicție asupra teritoriilor care găzduiesc populația ce a imigrat în numele unui criteriu diferit (de exemplu: etnicitatea) decât criteriul admis în mod tradiţional și canonic (teritoriul). Am amintit că delimitarea teritorială e fundamentală eclesiologiei ortodoxe pentru că ea subliniază unitatea Bisericii. Episcopii își recunosc reciproc episcopatul și plinătatea bisericilor locale asupra cărora prezidează. Principiul teritorial e fundamentat canonic pe primul și al patrulea Sinod Ecumenic, care condamnă încălcarea jurisdicției episcopilor (o Biserică - o Euharisite - un episcop - un teritoriu). Limitele teritoriilor canonice ale diferitelor biserici locale au fost stabilite încă din timpurile apostolice, iar mai târziu de către Sinoadele Ecumenice ${ }^{18}$.

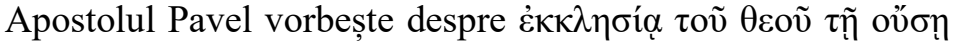

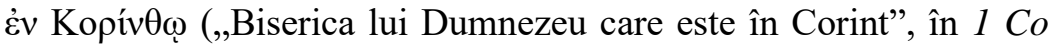
1, 2), care indică prezența integrității Bisericii într-o locaţie geografică specifică. În acest sens, M. Hämmerli consideră că numele oficiale ale bisericilor precum „Biserica Ortodoxă Rusă”, „Biserica Ortodoxă Română sunt derutante, în sensul că determinantul etnic creează impresia că denumirea „Română” şi „Rusă” descriu diferite tipuri de ortodoxie. În realitate, denumirea mult mai corectă ar fi „Biserica Ortodoxă din România ”, „Biserica Ortodoxă din Rusia etc ${ }^{19}$.

Cunoaştem că partea vestică a Europei a fost, tradițional vorbind, sub jurisdicția Episcopului Romei. Acesta nemaifiind în comuniune cu Biserica Ortodoxă (oficial din secolul al XI-lea), jurisdicția sa asupra teritoriului respectiv nu mai este recunoscută.

imperative pastorale", în Biserica Ortodoxă și provocările viitorului, ed. Mihai Himcinschi/Răzvan Brudiu, Cluj-Napoca/Alba Iulia, Editura Presa Universitară Clujeană/Reîntregirea, 2020, p. 334-335.

18 Maria HäMmERLI, „Orthodox diaspora? A sociological and theological problematisation...", p. 109.

19 Maria HäMmERLI, „Orthodox diaspora? A sociological and theological problematisation...”, p. 109. 
Bisericile Ortodoxe Naționale, în dorința lor de a da răspuns la nevoile pastoral-misionare ale comunităților respective, au creat noi eparhii în Vest şi au introdus o ierarhie paralelă. M. Hämmerli atrage atenția asupra faptului că din cauza acestor situații reale apar câteva probleme: prima se referă la încălcarea principiului teritorialității: Bisericile naționale autocefale și-au extins jurisdicția dincolo de teritoriul lor, ale căror limite au fost stabilite canonic, provocând suprapunerea jurisdicțiilor ortodoxe. În cazul Parisului, credincioșii ortodocși au cinci episcopi în loc de unul: fiecare dintre ei are teoretic un ,teritoriu” diferit: propria sa „turmă” etnică. Ei recunosc episcopatul celuilalt și nu interferează cu ,populația țintă” a celuilalt. $\mathrm{Cu}$ toate acestea, acest lucru slăbește unitatea Bisericii Ortodoxe până la punctul de a ajunge la imaginea unei federații de biserici naționale. Co-teritorialitatea, coexistența mai multor biserici locale în aceeaşi localizare geografică pe același teritoriu eclezial, este legată istoric de confesionalism, care a apărut ca o consecință a rupturii ecleziastice în Vest (separarea bisericii după Reformă). În cazul Ortodoxiei, problemele unității eclesiologice au introdus co-teritorialitatea diferitelor jurisdicții din Vest. Mulți se împacă cu separările administrative, invocând unitatea în credință și Taine. Totuşi, acest lucru nu este suficient, tocmai pentru că Euharistia și toate sacramentele sunt încorporate teritorial ${ }^{20}$.

A doua problemă se referă la etnofiletism: jurisdicția se exercită asupra persoanelor cu o anumită origine etnică şi nu asupra tuturor oamenilor din acel teritoriu. Există o trecere de la criteriul unic pentru stabilirea parohiilor şi eparhiilor (granițele teritoriale canonice) la etnie. Deşi, această deviere eclesiologică este de obicei atribuită diasporei, ea se extinde și la teritoriile ortodoxe tradiționale. Jurisdicții paralele există și în Republica Moldova (Patriarhia Moscovei și Biserica Ortodoxă Română) și Estonia (Patriarhia Moscovei și Patriarhia Ecumenică a Constantinopolului) sau pentru a cita un alt exemplu, Biserica Ortodoxă Română a

${ }^{20}$ Grégoire PAPATHOMAS, „La relation d'opposition entre Église établie localement et diaspora ecclésiale", Contacts, 210/2005, p. 96-132; Maria HÄMmERLI, „Orthodox diaspora? A sociological and theological problematisation...”, p. 110. 
numit un episcop pentru populația română care trăiește la granițele României, în Serbia Ortodoxă vecină ${ }^{21}$.

A treia problemă se referă la diminuarea sau limitarea universalității Bisericii: promovarea ideii potrivit căreia Biserica Ortodoxă, atunci când se manifestă în afara teritoriilor sale tradiționale, se află în diaspora. Diaspora presupune existența unui centru al Ortodoxiei, față de care o Ortodoxie neconformă acestui principiu de centralitate ar fi mai puțin Ortodoxă $\breve{c}^{22}$. Acest lucru este confirmat, în continuare, de relația pe care Bisericile Mame o au cu episcopiile, arhiepiscopiile sau mitropoliile din Vest: mențin poziția de putere a „mamelor” care nu permit „fiicelor” lor să crească și să devină autonome. $\mathrm{Cu}$ toate acestea, respectiva idee are nevoie de nuanțe, deoarece „fiicele” nu sunt întotdeauna suficient de mature pentru a dobândi și gestiona autonomia, astfel încât să și rămână în acelaşi timp înrădăcinate în Tradiție și în experiența Bisericii ${ }^{23}$.

În continuare analizăm câteva situații concrete ale diferitelor tensiuni dintre puterea seculară și cea religioasă. De exemplu, dezbaterile despre simbolurile religioase în spațiile publice în general, și aici amintim cazul Italiei, unde câțiva părinți au reacționat afirmând că prezența crucifixelor în școli înseamnă îndoctrinare excesivă, ajungându-se la acţiuni în instanţă pentru eliminarea acestora. În urma sesizării Curţii Europene a Drepturilor Omului, asupra utilizării simbolurilor religioase şi, în special, a crucifixelor în sălile de clasă din şcolile publice italiene, la data de 18 martie 2011, Curtea a decis cu majoritate de voturi că prezența crucifixelor în sălile de clasă nu încalcă niciun articol din Convenţia Europeană a Drepturilor Omului referitoare la dreptul la educaţie. Astfel, CEDO a comunicat, pe 1 iunie 2010, lista statelor care s-au

21 Maria HämmerLI, „Orthodox diaspora? A sociological and theological problematisation...", p. 110.

22 În cazul de față o Ortodoxie se referă la o unitate administrativă ortodoxă, conform căreia o episcopie în diaspora care nu se raportează la acest centru al Ortodoxiei nu ar mai fi ortodoxă.

${ }^{23}$ Leonid, KISHKOVSKY, Orthodoxy in America: Diaspora or Church?, disponibil la http://orthodoxeurope.org/page/14/49.aspx\#7 (accesat la data de 12.03.2021). 
alăturat în mod oficial Italiei, în problema menţionată: Armenia, Bulgaria, Cipru, Grecia, Lituania, Malta, Monaco, San Marino, România şi Rusia. Cele 10 state amintite au solicitat în mod formal să aibă posibilitatea de a se prezenta ca parte terţă în cadrul procesului în care a fost incriminată Italia şi să poată susţine oficial, la CEDO, propriile observaţii ${ }^{24}$.

O altă situație se referă la procesiunile și diferitele servicii religioase în afara spațiului liturgic ale comunităţilor de migranţi. Putem aminti faptul că în majoritatea țărilor din vestul Europei sunt interzise sunetele clopotelor (ele pot fi auzite doar în anumite intervale orare pentru a nu deranja fonic sau trebuie să fie o anumită distanță de la lăcașul de cult până la primele locuințe), interzicerea procesiunilor în Vinerea Mare sau la sărbătorirea hramului unei biserici, interzicerea sonorizării în afara spațiului eclesial etc.

O nouă dezbatere care apare între secular și religios este învăţământul ortodox în școlile de stat. Cunoaștem faptul că în majoritatea țărilor europene, importanța educației religioase a fost recunoscută la nivel de politici educaționale. Studierea monoconfesională sau refuzul Statului de a include Religia în Curriculum-ul Național, în special în Franța, au încurajat și dinamizat Biserica Ortodoxă Română la intensificarea activității catehetice. Astfel, educaţia religioasă realizată prin cateheză a activat suplimentar cu cea din şcoală sau a constituit singura formă de educație a Bisericii. În acest sens, amintim un proiect inedit care s-a născut la iniţiativa eparhiilor ortodoxe românești din vestul Europei, care împreună cu profesorii Dorin și Monica Opriş au gândit un proiect pentru realizarea în condiții cât mai bune a educației religioase pentru copiii români din diaspora europeană ${ }^{25}$. De asemenea, datele spaţiului în permanentă reconfigurare, al cetățeniei multiple, al libertății religioase etc., evidențiază problema

24 Teofil TIA, „Preocupare pastorală prioritară și constantă a Bisericii RomanoCatolice din Italia: Predarea Religiei în învățământul public de stat”, în Religia și Școala. Cercetări pedagogice, studii, analize, coord. Dorin Opriș, Monica Opriș, București, Editura Didactică și Pedagogică, 2011, p. 112-113.

25 În acest sens, vezi Dorin OPRIȘ, Monica OPRIȘ, Curriculum creștin-ortodox pentru școlile parohiale duminicale, Alba Iulia, Editura Reîntregirea, 2010. 
proprietății și a excluderii sau includerii în spaţiu, problema normelor de organizare a spaţiului (incluzând și problema folosirii aceluiași spațiu liturgic de către comunități confesionale diferite) și cea a amprentei autorităţii de stat care definește și controlează frontierele dintre spaţiul privat și cel public, dar şi dinamica relaționării dintre cetățenii locali și cei de origine străină ${ }^{26}$.

Biserica Ortodoxă Română a avut această obișnuință și a continuat să poarte de grijă față de credincioșii ei stabiliți în afara granițelor țării, călăuzită fiind de principiul unei organizări dinamice a Ortodoxiei, în care purtarea de grijă față de propriii credincioși trebuie să primeze înaintea oricărei limitări teritoriale. Conform Statutului Bisericii Ortodoxe Române publicat în anul 2020, Patriarhia Română deține următoarele eparhii în afara granițelor țării: Mitropolia Basarabiei, Mitropolia Ortodoxă Română a Europei Occidentale și Meridionale, Mitropolia Ortodoxă Română a Germaniei, Europei Centrale și de Nord, Mitropolia Ortodoxă Română a celor două Americi, Episcopia Daciei Felix, Episcopia Ortodoxă Română a Ungariei, Episcopia Ortodoxă Română a Australiei și Noii Zeelande. Amintim, de asemenea, reprezentanțele și comunitățile Patriarhiei Române în străinătate $^{27}$. În anul 2009, Sfântul Sinod al Bisericii Ortodoxe Române, a hotărât instituirea în Patriarhia Română a „Duminicii migranților români”, în prima duminică după 15 august.

Astăzi, comunitățile diasporale, în general, dar și Diaspora Ortodoxă românească, în special, păstrează legătura cu Patria Mamă şi cu alte grupări de co-naționali care sunt dispersați în lume prin urmărirea știrilor sociale și politice în timp real, prin conexiune TV, prin satelit, prin web și prin internet. Aceștia se află în contact virtual cu familiile și prietenii prin e-mail, skype, mesaje, Facebook, Twitter etc. Costul ieftin al apelurilor telefonice și al călătoriilor internaționale în comparație cu vremurile trecute, au făcut să crească frecvența și intensitatea contactului cu Patria Mamă, prin urmare, întărind identitatea națională a diasporei.

${ }^{26}$ Octavian MıHOC, „Identitatea religioasă ca narațiune în spații...”, p. 167-168.

${ }^{27}$ Pentru mai multe detalii, vezi Ioan CozMA, „Diaspora Ortodoxă: canonicitate și imperative pastorale...", p. 341 . 
Extinsele rețele transnaționale de diaspore creează un stat neteritorial, care, deși simbolic și emoțional se află conectat la centrul național, are o existență autonomă care poate să nu implice Patria Mamă în mod direct. De-teritorializarea identităților sociale este o caracteristică a globalizării și permite coexistența multiplelor identități și un sincretism al culturilor, o condiție care, de fapt, conduce spre împuternicirea identităţilor din diaspora ${ }^{28}$.

\section{Concluzii}

În Epistola către Diognet, autorul descrie astfel creștinii: „Deși ei locuiesc în orașele grecilor și ale barbarilor, după cum i-a fost sortit fiecăruia şi urmează obiceiurile locale privind îmbrăcămintea, mâncarea și restul vieții [...] ei locuiesc în țările lor, dar sunt doar călători; ei împlinesc toate îndatoririle ca cetățenii și suportă toate batjocurile ca străinii. Orice țară străină le este lor patrie, și orice patrie este pentru ei o țară străină [...] Traiul lor e pe pământ, dar cetățenia lor e în ceruri" ${ }^{29}$. Noua înțelegere pe care creștinismul a adus-o omenirii este una care depășește orice barieră etnică și naţională. Creștinismul este anterior creării statelor moderne. Acesta nu neagă realitatea etnică și culturală a existenței societăților umane pe pământ, dar caută să depășească această realitate. Adevărata patrie a creștinilor este Împărăția Cerurilor și, aici pe pământ, Biserica. Astfel, parafrazându-l pe Hans de Wit, afirmăm că în diaspora, patria este Biserica.

În Biserică ar trebui să fie depășite toate nostalgiile naționaliste, deoarece Biserica este o prefigurare a Împărăției, unde nu mai este nici grec, nici iudeu [...] fiindcă toți suntem una în Hristos Iisus $(G a 3,28)$. Sfântul Sofronie de la Essex menţionează în scrierile sale faptul că în credința creștină este vorba nu de lepădarea altor naționalități, ci de biruirea respectivelor limitări

28 Panagoula Diamanti-Karanou, The Relationship between Homeland and Diaspora: the Case of Greece..., p. 36; Robin COHEN, Global Diasporas: An Introduction, Seattle: University of Washington Press, 1997.

29 Traducere din Alfonso ROPERO, Obras escogidas de los padres apostólicos, Barcelona, Editorial Clie, 2018, p. 292-293. 
printr-o înălțare către rugăciunea cea din Ghetsimani. Dacă îl reducem pe Hristos la nivelul naționalității, atunci cu siguranță suntem în întuneric. Creștinul trebuie să-l aibă permanent în conștiința lui pe Hristos, să trăiască lumea ca pe un singur Adam și să se roage pentru întregul Adam $^{30}$. Acestea ne fac să realizăm că, oriunde am trăi, mereu suntem în „diaspora”, chiar și înăuntrul granițelor trasate de înaintașii noștri, în pământul pe care ei 1-au locuit. Adevărul acesta va păli odată cu epoca modernă și cu aprinderea scânteilor naționaliste, dar el rămâne peren, fiind singura mângâiere pe care creștinii o pot avea până la Parusie.

De asemenea, membrii Bisericii s-au lovit de chestiunea căsătoriilor mixte, și au ajuns la următoarea concluzie: convertirea sau despărțirea. Însă, dată fiind diversitatea etnică și culturală în care Biserica Ortodoxă își desfășoară misiunea în lume la ora actuală, nu trebuie să fim surprinși de faptul că fiecare Biserică Ortodoxă în parte a aplicat şi continuă să aplice principiile iconomiei și acriviei canonice faţă de căsătoriile mixte într-o manieră neunitară. Creștinii de astăzi aprofundează şi aduc abordări noi asupra credinței lor strămoșești, experimentând o revitalizare a credinței, într-un pământ străin și printre niște străini de această credință.

$\cos 8$

\section{Bibliografie}

1. CozMA, Ioan, „Căsătoriile mixte în teoria și practica Bisericii Ortodoxe", în Altarul Reîntregirii, 2/2010.

2. IDEM, „Diaspora Ortodoxă: canonicitate și imperative pastorale”, în Biserica Ortodoxă și provocările viitorului, ed. Mihai Himcinschi/Răzvan Brudiu, Cluj-Napoca/Alba Iulia, Editura Presa Universitară Clujeană/Reîntregirea, 2020, p. 334-335.

3. DE WIT, Hans, En la dispersión el texto es patria, San José, Universidad Bíblica Latinoamericana, 2002.

30 Arhimandritul Sofronie, Cuvântări duhovnicești, trad. Rafail (Noica), vol. I, Suceava, Editura Accent Print, 2013, p. 34, 43. 
4. Diamanti-KARANOU, Panagoula, The Relationship between Homeland and Diaspora: the Case of Greece and the GreekAmerican community, Northeastern University Boston, Massachusetts April, 2015.

5. HÄMMERLI, Maria, „Orthodox diaspora? A sociological and theological problematisation of a stock phrase", in International Journal for the Study of the Christian Church, 10, 2-3/2010.

6 . $\dagger$ EPISCOPUl IGNATIE, Maladia ideologiei și terapia Adevărului, Huși, Editura Horeb, 2020.

7. KishKovsKY, Leonid, Orthodoxy in America: Diaspora or Church?, disponibil la http://orthodoxeurope.org/page/14/49. aspx\#7 (accesat la data de 12.03.2021).

8. Legiuirile Bisericii Ortodoxe Române, București, 1953.

9. †NIFON MIHĂIȚĂ, „Diaspora-o nouă tipologie misionară”, în Misiologie Ortodoxă, vol. I, coord. Valer Bel, București, Editura Basilica, 2021.

10. MiHOC, Octavian, „Identitatea religioasă ca narațiune în spații în constantă reconfigurare", în Biserica Ortodoxă și provocările viitorului, ed. Mihai Himcinschi/Răzvan Brudiu, ClujNapoca/Alba Iulia, Editura Presa Universitară Clujeană/Reîntregirea, 2020, p. 175-176.

11. Mitropolitul Augustin al Germaniei, Exarh al Europei Centrale, şi ceilalți membri ai Conferinței Episcopale Ortodoxe din Germania, Scrisoare către tineri despre iubire, sexualitate și căsătorie, Frankfurt am Main, 12 decembrie 2017, disponibil la https://basilica.ro/scrisoarea-bisericii-ortodoxe-din-germaniadespre-dragoste-sexualitate-si-casatorie-adresata-tinerilor/ (accesat la data de 12.03.2021).

12. OPRIȘ, Dorin, / Opriș, Monica, Curriculum creștin-ortodox pentru sscolile parohiale duminicale, Alba Iulia, Editura Reîntregirea, 2010.

13. *** Regulamentul autorităților canonice disciplinare și al instanțelor de judecată ale Bisericii Ortodoxe Române, București, Editura Institutului Biblic şi de Misiune Ortodoxă, 2015.

14. Roeber, Anthony, Mixed Marriages. An Orthodox Hystory, New York, St. Vladimir's Seminary Press, 2018.

15. Arhimandritul SOFRONIE, Cuvântări duhovnicești, trad. Rafail (Noica), vol. I, Suceava, Editura Accent Print, 2013.

16. TIA, Teofil, „Preocupare pastorală prioritară și constantă a Bisericii Romano-Catolice din Italia: Predarea Religiei în 
învățământul public de stat”, în Religia şi Școala. Cercetări pedagogice, studii, analize, coord. Dorin Opriș, Monica Opriș, București, Editura Didactică și Pedagogică, 2011.

17. TseTsIS, George, The Pastoral Dimension of Mixed Marriages, Athens, 2007. (versiunea în limba engleză a acestui studiu este disponibilă la http://www.apostolikidiakonia.gr/en_main/catehism/theologia_zoi/themata.asp?cat=poi m\&contents $=$ contents.asp $\&$ main $=$ SK_texts $\&$ file $=4 . h t m$, accesat la data de 16.03.2021).

18. VISCUSO, Patrick, / WILluMSEN, Kristopher L., „Marriage between Christians and Non-Christians: Orthodox and Roman Catholic Perspectives", în Journal of Ecumenical Studies, 31:3-4, Summer-Fall 1994.

19. Vlaicu, Patriciu, „Biserica Ortodoxă în fața problematicii căsătoriilor mixte", în Studii Teologice, 1/2012. 